\title{
Systematic Review of Diabetes Self-Management: Focusing on the Middle-Aged Population of Pakistan and Saudi Arabia
}

\author{
Rashid M. Ansari*, John B. Dixon, Colette J. Browning \\ Department of General Practice, School of Primary Health Care, MONASH University, Melbourne, Australia \\ Email: ${ }^{*}$ rashid.ansari@monash.edu
}

Received 18 January 2015; accepted 3 February 2015; published 6 February 2015

Copyright (C) 2015 by authors and Scientific Research Publishing Inc.

This work is licensed under the Creative Commons Attribution International License (CC BY). http://creativecommons.org/licenses/by/4.0/

(c) (i) Open Access

\section{Abstract}

The aim is to synthesize the most contemporary qualitative research on the self-management of type 2 diabetes with specific interest in the population of Pakistan and Saudi Arabia. The electronic databases searched include the Cochrane library, MEDLINE, PubMed, EMBASE and PsycINFO, between the year 1993 and 2013. The inclusion criteria was the middle-aged population aged 40 60 years. Studies must report qualitative research on diabetes self-management, diabetic complications, quality of life, and patient-doctor relationship or interaction. Out of the 36 identified studies, 30 studies from the literature search representing self-management in context suggest that the multiple contextual factors identified are the fertile ground for further research, and the context which is useful for health care professionals suggests that coping with diagnosis and living with diabetes are affected by a complex constellation of factors, including life circumstances, social support, gender roles and economy. Three conceptual themes were identified from the analysis. The review has revealed that there is a lack of studies in literature on self-management of type 2 diabetes in both the countries.

\section{Keywords}

Type 2 Diabetes, Evidence-Based Analysis, Socio-Ecological Approach, Semi-Structured Qualitative Interviews, Self-Management of Type 2 Diabetes

\footnotetext{
${ }^{*}$ Corresponding author.
} 


\section{Introduction}

This systematic review of qualitative studies on self-management of type 2 diabetes is focusing on the middleaged population of Pakistan and Saudi Arabia, as there appears to be inadequate utilization of established evidence-based guidelines for self-management in these countries [1] and implementing the practice recommendations to care in these countries [2]. The systematic review is an ideal mechanism for clearly identifying "knowledge gaps" which will be useful to identify the need for self-management approaches for patients with type 2 diabetes and the assessment of quality of diabetes care in the community which can help draw attention to the measures required to improve diabetes self-management and provide a benchmark for monitoring changes over time. It has been demonstrated that patients who self-manage well tend to have better health outcomes, in terms of symptom control, health services utilization, and disease activity [3].

We consider here self-management in the broader context of managing the chronic disease - the way the patient is engaged and supported at various levels in obtaining the skills needed for optimal self-management. Therefore, self-management implies an intrapersonal understanding of diabetes control and some qualitative studies are worth mentioning here for the insights offered concerning the challenges that exist for integration of diabetes in terms of personal qualities of the self, identity, and individual experience [4] [5].

The importance of factors external to the self in diabetes management was acknowledged by Paterson et al. [5] who drew attention to the role of health care professionals in "transformative" experiences; they conceptualized this as a dynamic, interpersonal process between doctor and patient and suggested that when it worked well, it offered patients a great deal of benefits [5]. However, unsatisfactory relationships with healthcare professionals could lead to a lack of trust and abandonment of self-management recommendations. Therefore, the management of diabetes appears to operate on multiple levels: first, internally, in terms of personal identity and self, and externally, in terms of cultural resources and inter-subjective realities of medical consultations [6].

A study conducted in Pakistan on diabetes knowledge, beliefs and practices among people with diabetes [7] provided evidence that there was a lack of information available to people with diabetes in Pakistan as a large proportion of the population had never received any diabetes education on self-management at all [7]. This study might have underestimated the extent of the problem as it was conducted in an urban university hospital setting, where diabetes education might be more readily available compared with rural areas where people had less access to information and might have even poorer understanding of diabetes and the importance of self-management practices.

The health care system in Pakistan is encountered with many problems such as structural fragmentation, resource scarcity, inefficiency and a lack of functional specificity, and gender insensitivity and inaccessibility [8]. The $66 \%$ population living in rural areas face inadequately organized primary care services which are slowing down progress in health indicators [9]. In Pakistan, basic health units are seeing an average of $20-25$ patients per day where each basic unit has about 10 staff members. The primary care delivery system and satisfaction level have largely remained unchanged during the last three decades. The recent surveys indicate that nationally not more than $20 \%$ of the people use the first level public sector network for their health care needs [10] [11]. Therefore, the economic constraints, a lack of good governance and inability to deliver public goods have led to the concept of "unleashing the primary care to contracting services" in Pakistan [12].

The health services in the community in Pakistan are not adequate and diabetes health management programmes in the community health clinics do not provide enough help and support to the patients. Shortage of community doctors and expensive consultations with doctors make the life of patients more difficult in terms of managing their diabetes, particularly in the poor areas of Pakistan [8] [9]. These clinics in poor regions or in rural areas of Pakistan face special challenges in providing diabetes care to the poor patients, as most of these clinics do not meet the evidence-based quality of care standards as compared with the targets established by the American Diabetes Association [1].

Similar cases have been reported in several studies in diverse health care settings from low SES areas in various countries other than Pakistan, including academic institutions [13], health maintenance organization [14], health centers [15] and medical providers [16], where a substantial portion of diabetes care does not meet the evidence-based quality of standard care. Marshall et al. [17] have reported that community-based health clinics and their patients have fewer resources than the private clinics, that the community-based clinics often lack access to integrated delivery system, and that their small size limits the financial feasibility of full-time teams devoted solely to diabetes care. 
In Saudi Arabia, diabetes care is mostly integrated into the public health system through primary health care [18]. Usually, people with diabetes complications are referred from primary health-care centres to specialist diabetes centres. There are two reasons for this approach. The first reason is that the health care interventions to manage diabetes cases start with the registration of the patient in a primary health care centre and the issuing of diabetes card. Medical diagnosis includes a physical examination and laboratory studies in the primary health care setting. In addition to medical treatment, management includes patient education using the diabetes patients' education guidelines. The aim of these steps is to diagnose diabetes and prevent complications and when diabetes complications occur, the role of diabetes centres in primary care setting is to manage as well as refer patients to specialist care, such as those in cardiology or surgical departments.

In Saudi Arabia, although the health services are provided on a large scale across the country, diabetes services may need further development and coordination in order to facilitate and improve diabetes care outcomes, especially in the event of the anticipated increase in the prevalence of diabetes in Saudi Arabia [19]-[22]. Saudi Arabia is among the top 10 countries in the world for prevalence of diabetes among the age group between 20 and 79 years [23]. For comparison purposes, the prevalence of diabetes in the world is $8.3 \%$, in Saudi Arabia it is $23.4 \%$, in Pakistan it is $7.89 \%$, and in Australia the prevalence of diabetes has reached 9.55\% [23]. In Saudi Arabia, diabetes prevalence reaches a peak in the 40 - 60 age group, the second highest prevalence rate is for age group between 15 and 44 years and the third highest for the age group over the age sixty.

On the basis of the highest age-specific prevalence of diabetes ( 40 - 60 years) in both the countries and in line with the latest estimates of International Diabetes Federation on the greatest number of people with diabetes between 40 and 59 years [23], this systematic review focuses on the middle-aged population of both the countries with diabetes aged between 40 and 60 years.

\section{Systematic Review of Self-Management}

\subsection{Aims and Objectives}

The systematic review of the literature was carried out to cover the self-management of type 2 diabetes with specific interest in the population of Pakistan and Saudi Arabia, aimed at capturing the contemporary qualitative research or mixed methods methodology on the self-management of type 2 diabetes. In this review of self-management of type 2 diabetes, the aim is to synthesize the most contemporary qualitative research on the self-management of type 2 diabetes; that is the literature that has been published in the last 20 years on the self-management. The main interest in this systematic review focusing on the factors that had been identified as playing important role in self-management and considered that a systematic review is a good way to obtain perspective on current direction and future research in that area. This systematic review will identify knowledge gaps and synthesize knowledge of the self-management of type 2 diabetes among the middle-aged population in both Pakistan and Saudi Arabia.

\subsection{Design Methods}

\subsubsection{Literature Search Strategy}

The following electronic databases were searched: the Cochrane library, Medline, PubMed and PsycINFO, between the year 1993 and 2013 (20 years back in time). References of all retrieved articles were checked for relevant studies. The search key words were type 2 diabetes, socio-ecological approach, semi-structured qualitative interviews, and self-management of type 2 diabetes. This search strategy led to the identification of 36 relevant articles and the brief summary of the selected literature is presented in Table 1.

\subsubsection{Inclusion Criteria}

The initial literature search was broad enough to scope the quantity of contemporary qualitative research on the self-management of type 2 diabetes. The inclusion criteria for the articles was that they should be published in peer-reviewed journals between January 1993 and August 2013, should be related to self-management of type 2 diabetes, should use qualitative methods and should be available in English language. Articles related to clinical and meta-analysis were included if self-management of type 2 diabetes was considered to be the main focus of the articles.

The other inclusion criteria was the middle-aged population aged 40 - 60 years (specific interest in the population of Pakistan and Saudi Arabia) with poorly controlled type 2 diabetes - in line with the highest number of 
Table 1. Summary of systematic review of self-management of type 2 diabetes.

\begin{tabular}{|c|c|c|c|}
\hline $\begin{array}{l}\text { Study Details } \\
\text { (Author, Year) }\end{array}$ & Sample Characteristics & Design/Methods & Results \\
\hline Adams, 2003 [27] & $\mathrm{n}=13$ Latina women & Interpretive phenomenology & $\begin{array}{l}\text { Patients viewed stress as causal in } \\
\text { diabetes. They found it difficult to diet in } \\
\text { cultural context, and religion was often } \\
\text { drawn on for support. }\end{array}$ \\
\hline Alcozer, 2000 [28] & $\begin{array}{l}\mathrm{n}=10 \text { Mexican women } \\
\text { Aged } 27 \text { to } 45 \text { years, living } \\
\text { with partners/spouses. }\end{array}$ & Narrative Interview & $\begin{array}{l}\text { Meaning of diabetes was "viewed as a } \\
\text { life threat with complications and a } \\
\text { shortened life". }\end{array}$ \\
\hline $\begin{array}{l}\text { Ahmadani et al., } 2012 \\
\text { [29] }\end{array}$ & $\mathrm{n}=110$ Pakistani patients & $\begin{array}{l}\text { Prospective studies } \\
\text { conducted in the month of } \\
\text { fasting }\end{array}$ & $\begin{array}{l}\text { Active glucose monitoring and patients } \\
\text { education helped to manage diabetes. }\end{array}$ \\
\hline $\begin{array}{l}\text { Ahmadani et al., } 2008 \\
{[30]}\end{array}$ & $\begin{array}{l}\mathrm{n}=327 \text { Pakistani patients with } \\
\text { fasting }\end{array}$ & $\begin{array}{l}\text { Questionnaire based survey } \\
\text { of self-management }\end{array}$ & $\begin{array}{l}\text { Patients required special attention on } \\
\text { self-management of diabetes during the } \\
\text { fasting period. }\end{array}$ \\
\hline $\begin{array}{l}\text { Broom and Whittaker, } \\
2004[31]\end{array}$ & $\begin{array}{l}\mathrm{n}=119 \text { people with diabetes, } \\
56 \text { service providers, } 52 \% \text { men } \\
\text { aged } 20 \text { to } 90 \text { years. }\end{array}$ & $\begin{array}{l}\text { Unstructured interview of } \\
\text { self-management }\end{array}$ & $\begin{array}{l}\text { People concept of diabetes } \\
\text { self-management is that of discipline and } \\
\text { control. Attempts to avoid stigma might } \\
\text { undermine agency for management. }\end{array}$ \\
\hline $\begin{array}{l}\text { Balcou-Debussche and } \\
\text { Debussche, } 2009 \text { [32] }\end{array}$ & $\begin{array}{l}\mathrm{n}=42 \text { Creole people with type } \\
2 \text { diabetes; } 28 \text { women aged } 17 \\
\text { to } 72 \text { years }\end{array}$ & $\begin{array}{l}\text { Semi-structured interviews of } \\
\text { self-management }\end{array}$ & $\begin{array}{l}\text { Patients experienced a "suspension of } \\
\text { reality" in the hospital: everyday } \\
\text { constraints of home life were pended, } \\
\text { facilitating diabetes management. }\end{array}$ \\
\hline $\begin{array}{l}\text { Chasens and } \\
\text { Olshansky, } 2006[33]\end{array}$ & $\begin{array}{l}\mathrm{n}=17 \text { people with type } 2 \\
\text { diabetes; } 35 \% \text { men and } 65 \% \\
\text { women. Mean age } 55 \text { years. }\end{array}$ & $\begin{array}{l}3 \text { focus groups; analysis of } \\
\text { grounded theory }\end{array}$ & $\begin{array}{l}\text { Explored the ways in which sleepiness } \\
\text { constrained self-management. }\end{array}$ \\
\hline $\begin{array}{l}\text { Chun and Chelsea, } \\
2004[34]\end{array}$ & $\begin{array}{l}\mathrm{n}=16 \text { Chinese American } \\
\text { families; mean age }=60 \text { years }\end{array}$ & Group interviews & $\begin{array}{l}\text { Culturally related responses and } \\
\text { experiences of type } 2 \text { diabetes. }\end{array}$ \\
\hline $\begin{array}{l}\text { Chelsea and Shun, } \\
2005[35]\end{array}$ & $\begin{array}{l}\mathrm{n}=16 \text { Chinese American } \\
\text { families; mean age }=60 \text { years }\end{array}$ & Narrative group interviews & $\begin{array}{l}\text { Accommodation was the key response to } \\
\text { diabetes and consisted of practices and } \\
\text { concerns to balance quality of life. }\end{array}$ \\
\hline Fagerli et al., 2005 [36] & $\begin{array}{l}\mathrm{n}=15 \text { Pakistanis-born people } \\
\text { with diabetes living in Oslo, } 4 \\
\text { men, } 11 \text { women; age range } 38 \text { - } \\
66 \text { years. }\end{array}$ & Semi-structured interviews & $\begin{array}{l}\text { A number of constraints were } \\
\text { found-Discontinuity between different } \\
\text { types of culturally mediated lay } \\
\text { understanding. }\end{array}$ \\
\hline Furler et al., 2008 [37] & $\begin{array}{l}\mathrm{n}=24 \text { women and } 26 \text { men; age } \\
\text { range } 50 \text { to } 80 \text { years. }\end{array}$ & $\begin{array}{l}\text { Four focus groups to elicit } \\
\text { "shared frames of meaning" } \\
\text { of people with diabetes in } \\
\text { communities }\end{array}$ & $\begin{array}{l}\text { Patients described the role of emotional } \\
\text { contexts (shock, fear and worry) in } \\
\text { self-management. These have influenced } \\
\text { approach to self-management }\end{array}$ \\
\hline $\begin{array}{l}\text { Greenhalgh et al., } 2011 \\
\text { [38] }\end{array}$ & $\begin{array}{l}\mathrm{n}=82 \text { patients, aged } 25-86 \\
\text { years, from } 6 \text { ethnic groups }\end{array}$ & $\begin{array}{l}\text { Quasi-naturalistic } \\
\text { story-gathering, analyzed } \\
\text { thematically. }\end{array}$ & $\begin{array}{l}\text { Self-management should take closer } \\
\text { account of over-arching storylines that } \\
\text { pattern experience of chronic illness. }\end{array}$ \\
\hline $\begin{array}{l}\text { Hawthorne and } \\
\text { Tomlinson, } 1999 \text { [39] }\end{array}$ & $\begin{array}{l}\mathrm{n}=201 \text { Pakistani patients, } 101 \\
\text { women and } 100 \text { men, } 24 \% \\
\text { knew how to manage diabetes. }\end{array}$ & $\begin{array}{l}\text { One to one semi-structured } \\
\text { interviews }\end{array}$ & $\begin{array}{l}\text { Uneducated women did not know much } \\
\text { about self-management-require culturally } \\
\text { appropriate, health education and } \\
\text { support. }\end{array}$ \\
\hline Huang et al., 2005 [40] & $\begin{array}{l}\mathrm{n}=28 \text { older people with type } 2 \\
\text { diabetes; age range } 65 \text { to } 88 \\
\text { years }(12 \text { men) }\end{array}$ & $\begin{array}{l}\text { Semi-structured interviews } \\
\text { analyzed with grounded } \\
\text { theory }\end{array}$ & $\begin{array}{l}\text { Patient's health care goals were social } \\
\text { and functional, as compared to } \\
\text { bio-medical. }\end{array}$ \\
\hline $\begin{array}{l}\text { Jezewski and Poss, } \\
2002[41]\end{array}$ & $\begin{array}{l}\mathrm{n}=22 \text { Mexican American with } \\
\text { type } 2 \text { diabetes; } 4 \text { men; age } \\
\text { range } 29 \text { - } 77 \text { years. }\end{array}$ & $\begin{array}{l}\text { Semi-structured interviews } \\
\text { followed by focus groups; } \\
\text { analyzed by grounded theory }\end{array}$ & $\begin{array}{l}\text { Patients' explanatory frameworks for } \\
\text { diabetes drew on both lay and biomedical } \\
\text { understandings. }\end{array}$ \\
\hline Keval, 2009 [42] & $\begin{array}{l}\mathrm{n}=18 \text { South Asian, } \\
\text { Gujarati-speaking United } \\
\text { Kingdom residents; } 10 \text { men; } \\
\text { age range } 40 \text { to } 88\end{array}$ & $\begin{array}{l}\text { Semi-structured interviews } \\
\text { analyzed by grounded theory }\end{array}$ & $\begin{array}{l}\text { Patients viewed their social and cultural } \\
\text { networks as facilitating self-management. }\end{array}$ \\
\hline $\begin{array}{l}\text { Khowaja and Waheed, } \\
2010[26]\end{array}$ & $\begin{array}{l}\mathrm{n}=500 \text { type } 2 \text { diabetic patients } \\
\text { in Agha Khan University } \\
\text { hospital Pakistan. Age range } \\
30-70 \text { Years }\end{array}$ & $\begin{array}{l}\text { Cross section study } \\
\text { design-interviews with } \\
\text { structured questionnaire. }\end{array}$ & $\begin{array}{l}\text { Self-management of diabetes is was } \\
\text { associated with clinically and statistically } \\
\text { better glycemic control. }\end{array}$ \\
\hline
\end{tabular}




\section{Continued}

\begin{tabular}{|c|c|c|c|}
\hline $\begin{array}{l}\text { Koopman et al., } 2004 \\
\text { [43] }\end{array}$ & $\begin{array}{l}\mathrm{n}=15 \text { people with type } 2 \\
\text { diabetes; age range } 24 \text { to } 70 \\
\text { years }\end{array}$ & $\begin{array}{l}\text { Semi-structured interview; } \\
\text { thematic analysis using a } \\
\text { continuous iterative process }\end{array}$ & $\begin{array}{l}\text { Physicians and patients often } \\
\text { misattributed symptoms of diabetes to } \\
\text { other causes. }\end{array}$ \\
\hline $\begin{array}{l}\text { Lawton et al., } 2006 \\
{[44]}\end{array}$ & $\begin{array}{l}\mathrm{n}=32 \text { Asian people with type } \\
2 \text { diabetes ( } 23 \text { Pakistani, } 9 \\
\text { Indian); } 15 \text { men; age range } 40 \\
\text { to } 70 \text { years }\end{array}$ & $\begin{array}{l}\text { Open-ended interviews; } \\
\text { analysis based on grounded } \\
\text { theory }\end{array}$ & $\begin{array}{l}\text { Patients' willingness to adhere to } \\
\text { physical activity - barriers included } \\
\text { obligations to others and lack of } \\
\text { culturally sensitive facilities. }\end{array}$ \\
\hline $\begin{array}{l}\text { Lawton et al., } 2005 \\
\text { [45] } \\
\text { (Study 1) }\end{array}$ & $\begin{array}{l}\mathrm{n}=40 \text { patients with type } 2 \\
\text { diabetes; } 18 \text { men, } 22 \text { women; } \\
\text { age range } 21 \text { to } 77 \text { years }\end{array}$ & $\begin{array}{l}3 \text { semi-structured interviews } \\
\text { at } 6 \text { months intervals; } \\
\text { grounded theory }\end{array}$ & $\begin{array}{l}\text { Health services delivery system was } \\
\text { influenced how patients perceived their } \\
\text { diabetes. }\end{array}$ \\
\hline $\begin{array}{l}\text { Lawton et al., } 2005 \\
\text { [46] } \\
\text { (Study 2) }\end{array}$ & $\begin{array}{l}\mathrm{n}=40 \text { patients with type } 2 \\
\text { diabetes; } 18 \text { men, } 22 \text { women; } \\
\text { age range } 21-77 \text { years }\end{array}$ & $\begin{array}{l}3 \text { semi-structured interviews } \\
\text { at } 6 \text { months intervals; } \\
\text { grounded theory }\end{array}$ & $\begin{array}{l}\text { Patients were satisfied with delivery of } \\
\text { diabetes support by specialist nurses. }\end{array}$ \\
\hline $\begin{array}{l}\text { Lawton et al., } 2004 \\
{[47]}\end{array}$ & $\begin{array}{l}\mathrm{n}=40 \text { patients with type } 2 \\
\text { diabetes; } 18 \text { men, } 22 \text { women; } \\
\text { age range } 21-77 \text { years }\end{array}$ & $\begin{array}{l}3 \text { semi-structured interviews } \\
\text { at } 6 \text { months intervals; } \\
\text { grounded theory }\end{array}$ & $\begin{array}{l}\text { Patients preferred blood glucose } \\
\text { monitoring for self-management. }\end{array}$ \\
\hline $\begin{array}{l}\text { Lawton et al., } 2008 \\
{[48]}\end{array}$ & $\begin{array}{l}\mathrm{n}=20 \text { people from Scotland } \\
\text { with type } 2 \text { diabetes; } 11 \text { men; } \\
\text { age range } 40 \text { to } 80 \text { years }\end{array}$ & $\begin{array}{l}\text { Semi-structured interview } \\
\text { analyzed with grounded } \\
\text { theory }\end{array}$ & $\begin{array}{l}\text { Experimental dimension of } \\
\text { self-management of diabetes points to the } \\
\text { direction of "self-beliefs" and } \\
\text { "intentions". }\end{array}$ \\
\hline $\begin{array}{l}\text { Macaden and Clarke, } \\
2006 \text { [49] }\end{array}$ & $\begin{array}{l}\mathrm{n}=20 \text { people with type } 2 \\
\text { diabetes; four focus groups } \\
\text { with "ethnic health } \\
\text { development workers". }\end{array}$ & $\begin{array}{l}\text { Focus group and "individual } \\
\text { interview" analyzed with } \\
\text { grounded theory }\end{array}$ & $\begin{array}{l}\text { Explored the issues influencing } \\
\text { perception of risk among South Asian } \\
\text { people with type } 2 \text { diabetes. Management } \\
\text { perceived as the responsibility of health } \\
\text { professionals. }\end{array}$ \\
\hline
\end{tabular}

Miller and Brown, 2005 [50]

Moser et al., 2008 [51]

Moser et al., 2008 [51]

Nasmith et al., 2004 [52]

Parry et al., 2006 [53]

Peel et al., 2005 [54]

Polzer and Miles, 2007 [55]

Poss et al., 2003 [56]

Rayman and Ellisson, 2004 [57] $\mathrm{n}=20$ people with diabetes; mean age 65 years (men), 56 years (women).

$\mathrm{n}=15$ people with type 2 diabetes residing in Holland

$\mathrm{n}=15$ people with type 2 diabetes

$\mathrm{n}=25$ in-depth interviews and 3 focus groups with patients; $52 \%$ men, $48 \%$ women

$\mathrm{n}=40$ patients with type 2 diabetes; 18 men, 22 women

$\mathrm{n}=40$ patients with type 2 diabetes; 18 men, 22 women

$\mathrm{n}=29$ African American people with type 2 diabetes; 10 men; age $42-73$

$\mathrm{n}=22$ Mexican American patients with type 2 diabetes; 4 men; age 29 - 77

$\mathrm{n}=14$ women with type 2 diabetes; age range 25 - 75 years
Semi-structured interview with focus on dietary management

Qualitative descriptive and exploratory design based on grounded theory

Semi-structured interviews analyzed with grounded theory

Interviews and focus groups audiotaped and transcribed; thematic sequential analysis used

3 in depth interviews with over a year; discourse analysis

3 in depth interviews over a year; discourse analysis

Semi-structured interviews analyzed using grounded theory

Interviews using Kleinman's questions to elicit

explanatory models; analyzed with grounded theory.

12 face to face and 2 phone interviews using a guided conversation approach; used grounded theory
Three type of adaptation to diabetic diet: cohesive, enmeshed, and disengaged

Delineated 4 phases of involved in "identifying with diabetes (comprehending, struggling, evaluating, and mastering).

7 categories of autonomy defined, including "identifying with diabetes, shared decision making, self-determination.

Patients perceived benefits in having individualized information and support.

Patients and physicians both valued access to multidisciplinary team. Patients perceived benefits receiving individualized information and support.

Men perceived diet as a family matter, women considered it as an individual concern.

Identified religious beliefs and management was impacted by these beliefs.

Patients used social networks as a source of support and information about local remedies.

Engaging in self-management often resulted in self-blame and negative effect. 


\begin{tabular}{llll} 
Continued & & & \\
\hline $\begin{array}{l}\text { Weiler and Crist, } 2009 \\
{[58]}\end{array}$ & $\begin{array}{l}\mathrm{n}=10 \text { Latino people with type } \\
\text { 2 diabetes; } 4 \text { men; age range } \\
46 \text { - 65 years }\end{array}$ & $\begin{array}{l}\text { Semi-structured interviews; } \\
\text { qualitative descriptive design } \\
\text { using grounded theory }\end{array}$ & $\begin{array}{l}\text { All aspects of self-management were } \\
\text { linked with aspects of the Latino social } \\
\text { context, including perceptions of illness } \\
\text { and social stigma of disease. }\end{array}$ \\
Wong et al., 2005 [59] & $\begin{array}{l}\mathrm{n}=12 \text { people with type 2 } \\
\text { diabetes }\end{array}$ & $\begin{array}{l}\text { Semi-structured telephone } \\
\text { interview analyzed with } \\
\text { grounded theory }\end{array}$ & $\begin{array}{l}\text { Men actively supported by wives in } \\
\text { self-management and women were only } \\
\text { passively supported by husbands. }\end{array}$ \\
Wu et al., 2008 [25] & $\begin{array}{l}\mathrm{n}=9 \text { people with type 2 } \\
\text { diabetes and recent cardiac } \\
\text { event. 3 men and 6 women; } \\
\text { age range 59 to 85 }\end{array}$ & $\begin{array}{l}\text { Open ended interviews; data } \\
\text { analyzed into codes and } \\
\text { interpretive framework }\end{array}$ & $\begin{array}{l}\text { Patients' self-confidence and confidence } \\
\text { in health professionals was shattered after } \\
\text { the cardiac event. }\end{array}$
\end{tabular}

diabetic patients within the age groups of 40 - 59 years reported by International Diabetic Federation [23]. In addition, studies must report qualitative research on diabetes self-management, diabetic complications, quality of life, and patient-doctor relationship or interaction.

\subsubsection{Exclusion Criteria}

The articles were excluded if their focus was theoretical or methodological, quantitative research only and were not related to diabetes self-management but otherwise related to diabetes. The placement of a time limit on the literature search (January 1993 to August 2013) is a common strategy (20 years back in time) to identify a manageable yet sufficiently broad sample for detailed analysis [6] [24].

\subsubsection{Outcome of Interest}

Qualitative descriptions or interpretations of personal view or social experiences in these societies on the selfmanagement of type 2 diabetes, healthcare system use, quality of life and identification of knowledge gaps for future research.

\section{PRISMA for Systematic Review Reporting}

According to reporting guidelines for systematic review, a PRISMA (Preferred Reporting Items for Systematic Reviews and Meta-Analysis), checklist and flow chart approach was used for this systematic review. This approach is an evidence-based minimum set of items for reporting in systematic reviews and meta-analysis. Figure 1 shows the flow scheme of the identified literature search under this systematic review.

\section{Data Analysis}

\section{Characteristics of the Identified Literature}

In the selected 36 articles, participant sample size varied from $n=9$ [25] to $\mathrm{n}=500$ [26] with the mean sample size of $n=54$. Principles of grounded theory was most frequently used to interpret transcribed semi-structured interview and focus group data and, researchers were interested in facets of experience associated with having type 2 diabetes and in developing new theories from the analysis of participant accounts. The identified literature in Table 1 shows that topics covered a number of different aspects of the experience of type 2 diabetes and its management.

\section{Results of Systematic Review}

In order to provide a contextualizing overview of the identified literature, an overall analysis of Table 1 reveals that the authors identified culturally mediated experiences of type 2 diabetes in terms of ethnic/cultural groups, provided perspectives of newly diagnosed patients, discussed the ways in which people with diabetes perceived health care professionals and service delivery and the social construction of diabetes management. However, there are not many studies found in literature search on self-management highlighting the patient-doctor interactions. There is also lack of studies in literature on self-management of type 2 diabetes in both Pakistan and Saudi Arabia.

Out of the 36 identified studies presented in Table 1, 30 studies from the literature search representing self- 


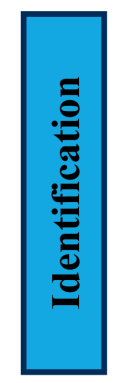

Literature Search: MEDLINE/PubMed/PsycInfo/EMBASE/Cochrane Library

- Diabetes (diabetes, type 2, type II)

- Health behaviour (self-management, self-care, lifestyle)

- Interpersonal relations (physician-patient relation, patient participation)

- Education (patient education, patient awareness, health promotion)

The proportion of irrelevant titles was reduced by adding publication-type restrictions

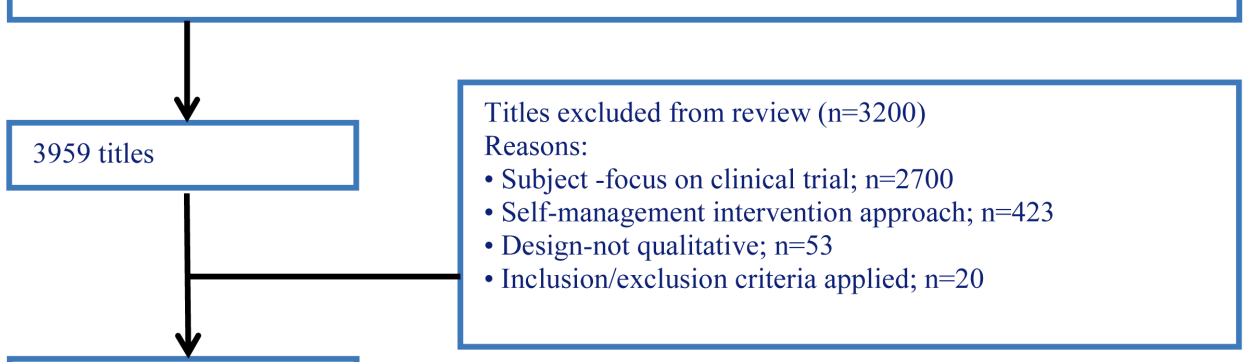

759 abstracts

Abstracts excluded from review $(\mathrm{n}=620)$

Reasons:

- Subject-about organization of healthcare; $\mathrm{n}=278$

- No self-management approach; $\mathrm{n}=280$

- Design - not qualitative research; $n=62$
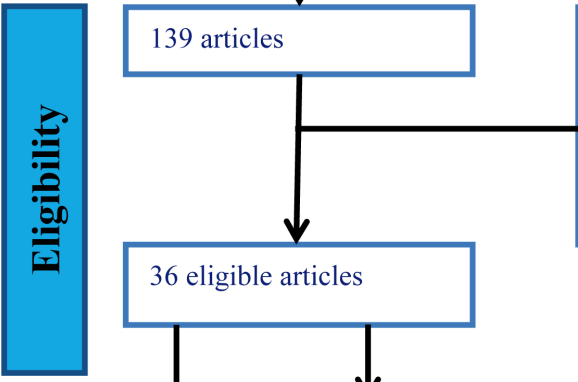

Articles excluded from review $(\mathrm{n}=103)$

Reasons:

- Subject-only biomedical parameters; $\mathrm{n}=52$

- No self-management approach; $\mathrm{n}=33$

- Design - not qualitative research; $\mathrm{n}=18$

36 eligible articles

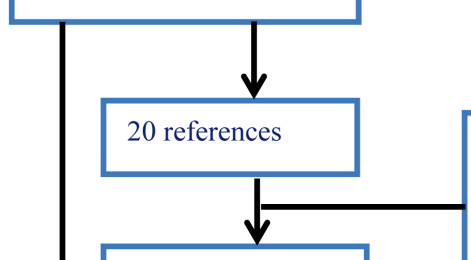

룽

References excluded from review $(\mathrm{n}=20)$

Reasons:

- Subject-focus on medical treatment; $\mathrm{n}=10$

- No self-management approach; $\mathrm{n}=5$

- Inclusion/exclusion criteria applied; $\mathrm{n}=5$

\section{Figure 1. Shows the flow scheme of the identified literature search under the systematic review.}

management in context, suggesting that the multiple contextual factors identified are fertile ground for further research, and that context should be given particular attention to gain particular attention to researchers to gain understanding of the process of diabetes management. The other 4 studies represent gender and self-management and 2 studies represented physician-patient relationship. Three conceptual themes were identified from the analysis of the identified literature. These themes are 1) self-management in context, 2) physician-patient interactions on self-management, and 3) gender and self-management. 


\section{Quality of Evidence of Selected Studies}

The field of qualitative research lacks consensus on the importance, methods, and standards of critical appraisal [60] and the qualitative health researchers underreport procedural details conventionally [61] and the quality of findings tends to rest less on methodological processes than on the conceptual prowess of the researchers [60]. The findings which are theoretically sophisticated are promoted as markers of study quality for making valuable theoretical contributions to social science academic discipline [62]. However, theoretical sophistication is not necessary for contributing potentially valuable information to a synthesis of multiple studies, nor to inform questions posed by the interdisciplinary and inter-professional field of health technology assessment [63].

In this particular review, we relied on the academic peer review and publication process to eliminate scientifically unsound studies according to current standards. We have also included all the relevant, accessible studies using qualitative interpretive or descriptive methodology. We appraised the value of the research findings solely in terms of their relevance to our research questions and the presence of data supported the authors' findings. We have considered studies in our selected sample that meet the selection criteria to be of higher quality. The three conceptual themes were used to examine the body of evidence shown in Table 2 and for each included study; the study design was identified and summarized and for each study included, the study location was identified and summarized.

\subsection{Self-Management in Context}

In the identified literature of Table 1, it was assumed by the authors and argued that a number of contextual factors impact diabetes self-management. Many authors developed analyses of the interrelationships between culture and diabetes self-management. Chun and Chelsea [34], and Chelsea and Chun [35], drew on a set of empirical data to explore the role of Chinese American "collectivist" culture in living with diabetes. While the participants in these studies expressed a view of their families as instrumental in offering emotional and practical support in living with diabetes, they have also noted problematic aspects to the collectivist context. These included placing the needs of the families above requirements for illness management and postponing it to take part in traditional celebrations involving food.

Table 2. Body of evidence examined according to conceptual themes, study design and study context.

\begin{tabular}{|c|c|c|c|}
\hline \multicolumn{4}{|c|}{ Body of evidence examined according to conceptual themes } \\
\hline Chronic Disease & Conceptual Theme 1 & Conceptual Theme 2 & Conceptual Theme 3 \\
\hline Type 2 diabetes & Self-management in context & Gender and self-management & Physician-patient interaction \\
\hline Nr. of studies & 30 & 4 & 2 \\
\hline \multicolumn{4}{|c|}{ Body of evidence examined according to study design } \\
\hline Study Design & \multicolumn{2}{|c|}{ Method of Analysis } & Nr. of Eligible Studies \\
\hline Qualitative Studies & \multicolumn{2}{|c|}{$\begin{array}{c}\text { Grounded theory } \\
\text { Content analysis } \\
\text { Questionnaire-based interviews } \\
\text { Narrative interviews } \\
\text { Framework analysis }\end{array}$} & $\begin{array}{c}19 \\
2 \\
9 \\
3 \\
3\end{array}$ \\
\hline Total & & & 36 \\
\hline \multicolumn{4}{|c|}{ Body of evidence examined according to study context } \\
\hline \multicolumn{2}{|c|}{ Study Context } & \multicolumn{2}{|c|}{ Number of Eligible Studies } \\
\hline \multicolumn{2}{|c|}{ Pakistan } & \multicolumn{2}{|r|}{1} \\
\hline \multicolumn{2}{|c|}{ Saudi Arabia } & \multicolumn{2}{|r|}{2} \\
\hline \multicolumn{2}{|c|}{ Australia } & \multicolumn{2}{|r|}{1} \\
\hline \multicolumn{2}{|c|}{ United States } & \multicolumn{2}{|r|}{20} \\
\hline \multicolumn{2}{|c|}{ United Kingdom } & \multicolumn{2}{|r|}{7} \\
\hline \multicolumn{2}{|c|}{ Scotland } & \multicolumn{2}{|r|}{2} \\
\hline \multicolumn{2}{|c|}{ Holland } & \multicolumn{2}{|r|}{2} \\
\hline \multicolumn{2}{|c|}{ Norway } & \multicolumn{2}{|r|}{1} \\
\hline \multicolumn{2}{|c|}{ Total } & \multicolumn{2}{|c|}{36} \\
\hline
\end{tabular}


A similar approach was evident in other three studies of Latin-Mexican American culture [27] [28] [58]. The participants in these studies described their cultural context in which immediate and extended families were viewed as a source of support. These social networks were confirmed and developed in Latin-Mexican American sub-cultures through community events; and refusing food at, or bringing diabetes - appropriate food to such events "would be considered rude to the hosts and would not be accepted" [58]. The lack of understanding of diabetes self-management exists in these cultures which might have constraining aspects for self-management.

Polzer and Miles [55] focused on the importance of spirituality for African Americans with diabetes, and found that the Christian faith was drawn on in various ways. Some participants considered role of God to be one of background support and took an active role in self-management of diabetes, whereas others viewed God more as a healer and were more passive in relation to self-management, believing outcomes to be in the hands of God. These contrasting understanding were associated with different approaches to diabetes self-management. Fagerli et al. [36] proposed after their investigation of experiences of dietary advice among Pakistani-born residents of Norway with type 2 diabetes that advice from health care professionals should be culturally and contextually sensitive.

A number of the Muslim Indian and Pakistani participants described by Lawton et al. [44] adopted the similar line of action believing that "it is in Allah's hands" [44] to cure them. The other studies carried out in Pakistan on diabetes education and awareness on self-management suggest that level of awareness at both physicians and patients along with other community people has been observed to be low [64]-[71]. It is evident from these studies that the different ways in which cultural understandings were drawn on by participants profoundly affected their approach to self-management.

\subsection{Physician-Patient Interactions}

The social interaction between the patients and doctors is of great significance. The patients of diabetes need to engage with a range of health professionals. Gaining knowledge of the patient's perspective builds on traditional models of physician-patient communication [72] provides greater clarity to the range of lay understandings that should be explored as a component of effective risk communication. Feudtner [73] has shown evidence of "victim blaming" between doctor and his patient and suggested that a "moralistic dialogue" emerged between the two parties.

In the searched literature, Lawton et al. [48] found that patients who had acted on advice from health professionals, but who continued to experience deterioration in their condition, were likely to reject the notion that their diabetes was controllable, and hence, decided not to adhere to dietary and behavioural recommendations. Conversely, when symptoms were minimized by drug treatment, some patients viewed their diabetes as having been cured and, therefore attempting to control their illness through self-management was no longer important [45] [46]. Moser et al. [51] identified in their theme "welcomed paternalism" that in achieving autonomy in diabetes care, some patients prefer the health care professionals to take the lead in the management of their disease. Similarly, Balcou-Debussche and Dubussche [32] found that participants appreciated some aspects of hospitalization that caused diabetes management to be placed temporarily in the hands of medical staff. These findings highlight the inter-relationship between self-management experiences, institutional contexts, and ways of interpersonal relating that impact how type 2 diabetes is perceived and experienced.

\subsection{Gender and Self-Management}

The other aspect of self-management identified in literature was that of influence of gender [27] [28] [54] [57]. These researchers explored the self-management specifically in relation to women and discussed the intersection of gender and culture. In the studies of Peel et al. [54], the question of how blame and accountability are constructed in accounts of dietary management, and gender emerged as fundamental. In the case of women, the diabetes management was considered as their own responsibility, which had to be negotiated within a family context.

In Pakistani and Saudi cultures women often subjugated their own needs to those of other family members, usually husbands and children, who preferred non-diabetic foods. The men in that society, by contrast viewed dietary change as a matter for their wives who were allocated the task of serving the "right" foods. Hence these men resisted shaping their own identity to the requirements of diabetes management by shifting the responsibility on others. The importance of the relative positions of men and women were acknowledged by Whittemore $e t$ 
al. [74], suggesting that women are primarily responsible for family meals and for overall family health and therefore, the diabetes management aimed at women might be particularly fruitful. Hence, the social and historical positioning of women as caregivers for children and husbands impacts how diabetes management is understood and enacted by the whole family.

In relation to women, several researchers have explored self-management [27] [28] [57] [74] found that diabetes management was sometimes mediated by cultural norms, such as the important role of Catholic faith as a source of support. The author suggested that women are largely responsible not only for the self-management of diabetes, but for the management of diabetes on other family members. The lack of specific research in the identified literature might echo a general cultural tendency to view men as normative and the experience of women of self-management may be considered to require specialist research.

\section{Discussions}

In this analysis, the qualitative research on type 2 diabetes on self-management was considered from January 1993 to August 2013 (20 years back in time) to identify sufficiently large sample for detailed analysis. An interesting feature of the literature synthesis is the way in which multiple levels of subjectivity were identified as pertinent to the process of self-management of type 2 diabetes. Many authors explored how cultural, bodily and spatial contexts impacts self-management of type 2 diabetes.

Also, the differences in the experiences of men and women, as identified in the literature, demonstrate that diabetes self-management has a gendered dimension. In particular, in the context of Pakistani and Saudi cultures, the structure of gendered roles within the family often meant that in comparison to men, women's effort to "selfmanage" were less likely to be supported by children and male partners, who were often unwilling to adopt diabetic-friendly diets.

The authors have also identified diabetes self-management as spatially contingent, with different spaces offering distinct opportunities to manage diabetes. The identified literature also reveals that diabetes management was conceptualized in individualist terms in which patients were given responsibility for management of diabetes, and "internal" psychological processes were frequently prioritized by both researchers and participants.

There is also a strong moral aspect to self-management, because deteriorating health due to diabetes is linked to a failing self, in particular a failure to self-control. It was also noted by Broom and Whittaker [31] that such understandings undermined the efforts of health professionals in managing the diabetes. It has also been understood from the identified literature that giving importance to the role of the individual downplays the role of cultural, interactional, material, and spatial factors in illness trajectory, instead placing accountability with patients themselves. Many authors in the identified literature found ways to enable individuals to take responsibility for the management of type 2 diabetes on a day to day basis and this was achieved by educating patients about the link between lifestyle, glycemic control, and comorbidity, providing the informed choices made by patients themselves.

In literature, although several authors indicated that educational information provided to patients on diabetes management was valued by study participants, the idea that people with diabetes have real choices if they want to remain well has been analyzed and critiqued as a rhetoric stemming from the values of rational individualism [75]. Some authors [31] [53] referred to the assumptions of individualism in discussions; none of them explicitly used "individualistic culture" as a framework through which to understand the practices and experiences in selfmanagement.

\section{Strengths and Weaknesses of Literature Synthesis}

The strengths of this literature synthesis include the search strategy that was systematically employed across relevant databases and criteria that ensured relevance of articles to the synthesis. The synthesis covers a wider range of articles over the period of 20 years and offers a unique critique of the idea of self-management that was brought to light by exploring the multiple social, interactional, and spatial contexts that the identified literature showed to be pertinent to diabetes self-management.

The other unique aspect of this literature search was that while it identified the articles on self-management over a longer period, it has also focused on the aspect of self-management in Pakistan and Saudi Arabia and highlighted the cultural, social and religious norms in self-management of type 2 diabetes in these two countries. The aim was to search the literature comprehensively on self-management of type 2 diabetes, in practice; this 
might have been an ideal approach, however, the inclusion criteria on the research articles might have created "selection bias", but debate continues around how best to proceed with literature searches, as there is no Cochrane "gold standard" exists for synthesizing qualitative research [76].

\section{Conclusions}

This systematic review has demonstrated that there are gaps in the literature that can be addressed by qualitative research approaches. The review has yielded important insights into the ways in which diabetes is viewed and managed in Pakistan and Saudi Arabia. The review has also revealed that there is a lack of studies in literature on self-management of type 2 diabetes in both the countries. This review will be useful for health care professionals suggesting that coping with diagnosis and living with diabetes are affected by a complex constellation of factors, including life circumstances, social support, gender roles and economy.

The review will also be helpful for patients with diabetes to enhance their knowledge and understanding of self-management of this chronic disease. There are not many studies found in the identified literature on selfmanagement where patient-doctor relationship has been specifically highlighted and that area is wide open for further research. It has been demonstrated in this systematic review that self-management of type 2 diabetes reflects the grounding of diabetes in the context of social, cultural and environmental influences.

This systematic review has also identified that in order to improve the quality health care for diabetes in health clinics, it will require a multifactorial approach emphasizing patient education, improved training in behavioural change for providers, and enhanced delivery system. The identified literature has identified the influence of gender on self-management of type 2 diabetes and suggested that women are primarily responsible for family meals and for overall family health, and therefore the diabetes management aimed at women may be particularly fruitful.

\section{Conflict of Interest Statement}

The authors declare that there are no conflicts of interest.

\section{References}

[1] American Diabetes Association (2006) Standards of Medical Care in Diabetes. Diabetes Care, 29, S4-S42.

[2] Rayappa, P.H., Raju, K.N.M., Kapur, A., et al. (1998) The Impact of Socio-Economic Factors on Diabetes Care. International Journal of Diabetes in Developing Countries, 19, 7-15.

[3] Thille, P., Ward, N. and Russell, G. (2014) Self-Management Support in Primary Care: Enactments, Disruptions, and conversational Consequences. Social Science and Medicine, 108, 97-105. http://dx.doi.org/10.1016/j.socscimed.2014.02.041

[4] Goldman, J.B. and Maclean, H.M. (1998) The Significance of Identity in the Adjustment to Diabetes among Insulin Users. Diabetes Educator, 24, 741-748. http://dx.doi.org/10.1177/014572179802400610

[5] Paterson, B.L., Thorne, S.E., Canam, C., et al. (2001) Meta-Study of Qualitative Research: A Practical Guide to Meta-Analysis and Meta-Synthesis. Thousand Oaks, Sage.

[6] Gomersall, T., Madill, A. and Summers, L.K.M. (2011) A Meta-Synthesis of the Self-Management of Type 2 Diabetes. Qualitative Health Research, 21, 853-871. http://dx.doi.org/10.1177/1049732311402096

[7] Rafique, G. and Shaikh, F. (2006) Identifying Needs and Barriers to Diabetes Education in Patients with Diabetes. Journal of Pakistan Medical Association, 56, 347-352.

[8] Shaikh, B.T., Rabbani, F., Safi, N., et al. (2010) Contracting of Primary Health Care Services in Pakistan: Is Up-Scaling a Pragmatic Thinking? Journal of Pakistan Medical Association, 60, 386-389.

[9] World Bank, Pakistan (2002) Poverty Assessment. Poverty in Pakistan: Vulnerabilities, Social Gaps, and Rural Dynamics. Poverty Reduction and Economic Management Sector Unit South Asia Region, 2002.

[10] Government of Pakistan (2000) Utilization of Public Health Facilities in Pakistan. National Health Management Information System, Islamabad.

[11] National Institute of Population Studies (2008) Pakistan Demographic and Health Survey 2006-07 Final Report. Islamabad.

[12] Nishtar, S. (2006) The Public-Private Interface: More than "a Driver of Economic Growth". Viewpoint, Pakistan Health Policy Forum, Heartfile, Islamabad.

[13] Peters, A.L., Legorreta, A.P., Ossorio, R.C. and Davidson, M.B. (1996) Quality of Outpatient Care Provided to Di- 
abetic Patients: A Health Maintenance Organization Experience. Diabetes Care, 19, 601-606.

http://dx.doi.org/10.2337/diacare.19.6.601

[14] Miller, K.L. and Hirsch, I.B. (1994) Physicians' Practices in Screening for the Development of Diabetic Nephropathy and the Use of Glycosylated Hemoglobin Levels. Diabetes Care, 17, 1495-1497. http://dx.doi.org/10.2337/diacare.17.12.1495

[15] Chin, M.H., Auerbach, S.B., Cook, S., Harrison, J.F., Koppert, J., Jin, L., et al. (2000) Quality of Diabetes Care in Community Health Centers. American Journal of Public Health, 90, 431-434. http://dx.doi.org/10.2105/AJPH.90.3.431

[16] Chin, M.H., Zhang, J.X. and Merrell, K. (1998) Diabetes in the African-American Medicare Population: Morbidity, Quality of Care, and Resource Utilization. Diabetes Care, 21, 1090-1095. http://dx.doi.org/10.2337/diacare.21.7.1090

[17] Marshall, M.N., Shekelle, P.G., Leatherman, S.T. and Brook, R.H. (2000) The Public Release of Performance Data What Do We Gain? A Review of Evidence. Journal of the American Medical Association, 283, 1866-1874. http://dx.doi.org/10.1001/jama.283.14.1866

[18] Al-Malki, M., Fitzgerald, G. and Clark, M. (2011) Health Care System in Saudi Arabia: An Overview. Eastern Mediterranean Health Journal, 17, 784-793.

[19] Alzaid, A. (1997) Time to Declare War on Diabetes. Annals of Saudi Medicine, 17, 154-155.

[20] Fatani, H.H., Mira, S.A. and El-Zubier, A.G. (1987) Prevalence of Diabetes Mellitus in Rural Saudi Arabia. Diabetes Care, 10, 180-183. http://dx.doi.org/10.2337/diacare.10.2.180

[21] El-Hazmi, M., Warsy, A.S., Al-Swailem, A. and Sulaimani, R. (1998) Diabetes Mellitus as a Health Problem in Saudi Arabia. Eastern Mediterranean Health Journal, 4, 58-67.

[22] Gilles, C.L., Abrams, K.R., Lambert, P.C., Cooper, N.J., Sutton, A.J., Hsu, R.T., et al. (2007) Pharmacological and Lifestyle Interventions to Prevent or Delay Type 2 Diabetes in People with Impaired Glucose Tolerance: Systematic Review and Meta-Analysis. British Medical Journal, 334, 299-307. http://dx.doi.org/10.1136/bmj.39063.689375.55

[23] Whiting, D.R., Guariguata, L., Weil, C., et al. (2011) IDF Diabetes Atlas: Global Estimates of the Prevalence of Diabetes for 2011 and 2030. Diabetes Research and Clinical Practice, 94, 311-321.

[24] Campbell, R., Pound, P., Pope, C., Brittenb, N., Pillc, R., Morgand, M., et al. (2003) Evaluating Meta-Ethnography: A Synthesis of Qualitative Research on Lay Experiences of Diabetes and Diabetes Care. Social Science \& Medicine, 56, 671-684. http://dx.doi.org/10.1016/S0277-9536(02)00064-3

[25] Wu, C.J., Chang, A.M. and McDowell, J. (2008) Perspectives of Patients with Type 2 Diabetes Following a Critical Cardiac Event-An Interpretive Approach. Journal of Clinical Nursing, 17, 16-24.

[26] Khowaja, K. and Waheed, H. (2010) Self-Glucose Monitoring and Glycaemic Control at a Tertiary Care University Hospital Karachi, Pakistan. Journal of Pakistan Medical Association, 60, 1035-1038.

[27] Adams, C.R. (2003) Lessons Learned from Urban Latinas with Type 2 Diabetes Mellitus. Journal of Transcultural Nursing, 14, 255-265. http://dx.doi.org/10.1177/1043659603014003012

[28] Alcozer, F. (2000) Secondary Analysis of Perceptions and Meanings of Type 2 Diabetes among Mexican American Women. Diabetes Educator, 26, 785-795. http://dx.doi.org/10.1177/014572170002600507

[29] Ahmadani, M.Y., Haque, M.S., Basit, A., Fawwad, A. and Alvi, S.F.D. (2012) Ramadan Prospective Diabetes Study: The Role of Drug Dosage and Timing Alteration, Active Glucose Monitoring and Patient Education. Diabetic Medicine, 29, 709-715. http://dx.doi.org/10.1111/j.1464-5491.2011.03563.x

[30] Ahmadani, M.Y., Riaz, M., Fawaad, A., Hydrie, M.Z.I., Hakeem, R. and Basit, A. (2008) Glycaemic Trend during Ramadan in Fasting Diabetic Subjects: A Study from Pakistan. Pakistan Journal of Biological Sciences, 11, $2044-2047$. http://dx.doi.org/10.3923/pjbs.2008.2044.2047

[31] Broom, D. and Whittaker, A. (2004) Controlling Diabetes: Moral Language in the Management of Diabetes Type 2. Social Science \& Medicine, 58, 2371-2382. http://dx.doi.org/10.1016/j.socscimed.2003.09.002

[32] Debussche, M. and Debussche, X. (2009) Hospitalization for Type 2 Diabetes: The Effects of the Suspension of Reality on Patients' Subsequent Management of Their Condition. Qualitative Health Research, 19, 1100-1115. http://dx.doi.org/10.1177/1049732309341642

[33] Chasens, E.R. and Olshansky, E. (2006) The Experience of Being Sleepy While Managing Type 2 Diabetes. Journal of the American Psychiatric Nurses Association, 12, 272-278. http://dx.doi.org/10.1177/1078390306295086

[34] Chun, K.M. and Chesla, C.A. (2004) Cultural Issues in Disease Management for Chinese Americans with Type 2 Diabetes. Psychology and Health, 19, 767-785. http://dx.doi.org/10.1080/08870440410001722958

[35] Chesla, C.A. and Chun, K.M. (2005) Accommodating Type 2 Diabetes in the Chinese American Family. Qualitative Health Research, 15, 240-255. http://dx.doi.org/10.1177/1049732304272050 
[36] Fagerli, R.A., Lien, M.E. and Wandel, M. (2005) Experience of Dietary Advice among Pakistani-Born Persons with Type 2 Diabetes in Oslo. Appetite, 45, 295-304. http://dx.doi.org/10.1016/j.appet.2005.07.003

[37] Furler, J., Walker, C., Blackberry, I., Dunning, T., Sulaiman, N., Dunbar, J., et al. (2008) The Emotional Context of Self-Management in Chronic Illness: A Qualitative Study of the Role of Health Professional Support in the Self-Management of Type 2 Diabetes. BMC Health Services Research, 8, 214-222. http://dx.doi.org/10.1186/1472-6963-8-214

[38] Greenhalgh, T., Collard, A., Campbell-Richards, D., Vijayaraghavan, S., Malik, F., Morris, J., et al. (2011) Storyline of Self-Management: Narratives of People with Diabetes from a Multiethnic Inner City Population. Journal of Health Services Research \& Policy, 16, 37-43. http://dx.doi.org/10.1258/jhsrp.2010.009160

[39] Hawthorne, K. and Tomlinson, S. (1999) Pakistani Moslems with Type 2 Diabetes Mellitus: Effect of Sex, Literacy Skills, Known Diabetic Complications and Place of Care on Diabetic Knowledge, Reported Self-Monitoring Management and Glycaemic Control. Diabetic Medicine, 16, 591-597. http://dx.doi.org/10.1046/j.1464-5491.1999.00102.x

[40] Huang, E.S., Gorawara-Bhat, R. and Chin, M.H. (2005) Self-Reported Goals of Older Patients with Type 2 Diabetes Mellitus. Journal of the American Geriatrics Society, 53, 306-311. http://dx.doi.org/10.1111/j.1532-5415.2005.53119.x

[41] Jezewski, M.A. and Poss, J. (2002) Mexican Americans' Explanatory Model of Type 2 Diabetes. Western Journal of Nursing Research, 24, 840-858. http://dx.doi.org/10.1177/019394502237695

[42] Keval, H. (2009) Cultural Negotiations in Health and Illness: The Experience of Type 2 Diabetes among GujaratiSpeaking South Asians in England. Diversity in Health and Care, 6, 255-265.

[43] Koopman, R.J., Mainous, A.G. and Jeffcoat, A.S. (2004) Moving from Undiagnosed to Diagnosed Diabetes: The Patient's Perspective. Family Medicine, 36, 727-732.

[44] Lawton, J., Ahmad, N., Hanna, L., Douglas, M. and Hallowell, N. (2006) "I Can’t Do Any Serious Exercise": Barriers to Physical Activity Amongst People of Pakistani and Indian Origin with Type 2 Diabetes. Health Education Research, 21, 43-54. http://dx.doi.org/10.1093/her/cyh042

[45] Lawton, J., Parry, O., Peel, E., Araoza, G. and Douglas, M. (2005) Lay Perceptions of Type 2 Diabetes in Scotland: Bringing Health Services Back in. Social Science \& Medicine, 60, 1423-1435. http://dx.doi.org/10.1016/j.socscimed.2004.08.013

[46] Lawton, J., Parry, O., Peel. E. and Douglas, M. (2005) Diabetes Service Provision: A Qualitative Study of Newly Diagnosed Type 2 Diabetes Patients' Experiences and Views. Diabetic Medicine, 22, 1246-1251. http://dx.doi.org/10.1111/j.1464-5491.2005.01619.x

[47] Lawton, J., Peel, E., Douglas, M. and Parry, O. (2004) "Urine Testing Is a Waste of Time”: Newly Diagnosed Type 2 Diabetes Patients' Perceptions of Self-Monitoring. Diabetic Medicine, 21, 1045-1048. http://dx.doi.org/10.1111/j.1464-5491.2004.01286.x

[48] Lawton, J., Peel, E., Parry, O. and Douglas, M. (2008) Shifting Accountability: A Longitudinal Qualitative Study of Diabetes Causation Accounts. Social Science and Medicine, 67, 47-56. http://dx.doi.org/10.1016/j.socscimed.2008.03.028

[49] Macaden, L. and Clarke, C.L. (2006) Risk Perception among Older South Asian People in the UK with Type 2 Diabetes. International Journal of Older People Nursing, 1, 177-181. http://dx.doi.org/10.1111/j.1748-3743.2006.00026.x

[50] Miller, D. and Brown, J.L. (2005) Marital Interactions in the Process of Dietary Change for Type 2 Diabetes. Journal of Nutrition Education and Behavior, 37, 226-234. http://dx.doi.org/10.1016/S1499-4046(06)60276-5

[51] Moser, A., van der Bruggen, H., Spreeuwenberg, C. and Widdershoven, G. (2008) Autonomy through Identification: A Qualitative Study of the Process of Identification Used by People with Type 2 Diabetes. Journal of Nursing and Healthcare of Chronic Illness, in Association with Journal of Clinical Nursing, 17, 209-216.

[52] Nasmith, L., Coté, B., Cox, J., Inkell, D., Rubenstein, H., Jimenez, V., et al. (2004) The Challenge of Promoting Integration: Conceptualization, Implementation, and Assessment of a Pilot Care Delivery Model for Patients with Type 2 Diabetes. Family Medicine, 36, 40-45.

[53] Parry, O., Peel, E., Douglas, M. and Lawton, J. (2006) Issues of Cause and Control in Patient Accounts of Type 2 Diabetes. Health Education Research, 21, 97-107. http://dx.doi.org/10.1093/her/cyh044

[54] Peel, E., Parry, O., Douglas, M. and Lawton, J. (2005) Taking the Biscuit? A Discursive Approach to Managing Diet in Type 2 Diabetes. Journal of Health Psychology, 10, 779-791. http://dx.doi.org/10.1177/1359105305057313

[55] Polzer, R.L. and Miles, M.S. (2007) Spirituality in Africa Americans with Diabetes: Self-Management through a Relationship with God. Qualitative Health Research, 17, 176-188. http://dx.doi.org/10.1177/1049732306297750

[56] Poss, J.E., Jezewski, M. and Stuart, A.G. (2003) Home Remedies for Type 2 Diabetes Used by Mexican Americans in El Paso, Texas. Clinical Nursing Research, 12, 304-323. http://dx.doi.org/10.1177/1054773803256872

[57] Rayman, K.M. and Ellison, G.C. (2004) Home Alone: The Experience of Women with Type 2 Diabetes Who Are New 
to Intensive Control. Health Care for Women International, 25, 900-915. http://dx.doi.org/10.1080/07399330490508604

[58] Weiler, D.M. and Crist, J. (2009) Diabetes Self-Management in a Latino Social Environment. Diabetes Educator, 35, 285-292. http://dx.doi.org/10.1177/0145721708329545

[59] Wong, M., Gucciardi, E., Li, L. and Grace, S.L. (2005) Gender and Nutrition Management in Type 2 Diabetes. Canadian Journal of Dietetic Practice and Research, 66, 215-220. http://dx.doi.org/10.3148/66.4.2005.215

[60] Melia, K. (2010) Recognizing Quality in Qualitative Research. In: Bourgeault, I. and DeVries, R., Eds., Handbook of Qualitative Research, Sage, Thousand Oaks, 559-574.

[61] Sandelowskin, M. and Barroso, J. (2007) Handbook of Synthesizing Qualitative Research. Springer, New York, 312 p.

[62] Sandelowski, M. (2002) Finding the Findings in Qualitative Studies. Journal of Nursing Scholarship, 34, 213-219. http://dx.doi.org/10.1111/j.1547-5069.2002.00213.x

[63] Saini, M. and Shlonsky, A. (2012) Systematic Synthesis of Qualitative Research. Oxford University Press, New York, 224 p. http://dx.doi.org/10.1093/acprof:oso/9780195387216.001.0001

[64] Ali, M., Khalid, G.H. and Pirkani, G.S. (1998) Level of Health Education in Patients with Type 2 Diabetes Mellitus in Quetta. Journal of Pakistan Medical Association, 48, 334-336.

[65] Jabbar, A., Contractor, Z., Ebrahim, M.A. and Mahmood, K. (2001) Standard of Knowledge about Their Disease among Patients with Diabetes in Karachi, Pakistan. Journal of Pakistan Medical Association, 51, 6-8.

[66] Shera, A.S., Jawad, F. and Basit, A. (2002) Diabetes Related Knowledge, Attitude and Practices of Family Physicians in Pakistan. Journal of Pakistan Medical Association, 52, 465-470.

[67] Hasan, Z.U., Zia, S. and Maracy, M. (2000) Baseline Disease Knowledge Assessment in Patients with Type 2 Diabetes in a Rural Area of Northwest of Pakistan. Journal of Pakistan Medical Association, 54, 67-73.

[68] Adil, M.M., Alam, A.Y. and Jaffery, T. (2005) Knowledge of Type 2 Diabetes Patients about Their Illness: Pilot Project. Journal of Pakistan Medical Association, 55, 221-224.

[69] Sabri, A.A., Qayyum, M.A., Saigol, N.U., Zafar, K. and Aslam, F. (2007) Comparing Knowledge of Diabetes Mellitus among Rural and Urban Diabetics. McGill Journal of Medicine, 10, 87-89.

[70] Ulvi, O.S., Chaudhary, R.Y., Ali, T., Alvi, R.A., Khan, M.F., Khan, M., et al. (2009) Investigating the Awareness Level about Diabetes Mellitus and Associated Factors in Rural Islamabad. Journal of Pakistan Medical Association, 59, 798-780.

[71] Afridi, M.A. and Khan, M.N (2003) Role of Health Education in the Management of Diabetes Mellitus. Journal of College of Physicians and Surgeons Pakistan, 13, 558-561.

[72] Pendleton, D., Schofield, T. and Tate, P. (1984) The Consultation: An Approach to Learning and Teaching. Oxford University Press, Oxford.

[73] Feudtner, C. (2003) Bittersweet: Diabetes, Insulin and Transformation of Illness. University of North Caroline Press, Chapel Hill.

[74] Whittemore, R., Chase, S., Mandle, C.L. and Roy, S.C. (2001) The Content, Integrity, and Efficacy of a Nurse Coaching Intervention in Type 2 Diabetes. Diabetes Educator, 27, 887-898. http://dx.doi.org/10.1177/014572170102700614

[75] Mol, A. (2008) The Logic of Care: Health and the Problem of Patient Choice. Routledge, Milton Park.

[76] Dixon-Woods, M., Booth, A. and Sutton, A.J. (2007) Synthesizing Qualitative Research: A Review of Published Reports. Qualitative Research, 7, 375-422. http://dx.doi.org/10.1177/1468794107078517 
Scientific Research Publishing (SCIRP) is one of the largest Open Access journal publishers. It is currently publishing more than 200 open access, online, peer-reviewed journals covering a wide range of academic disciplines. SCIRP serves the worldwide academic communities and contributes to the progress and application of science with its publication.

Other selected journals from SCIRP are listed as below. Submit your manuscript to us via either submit@scirp.org or Online Submission Portal.
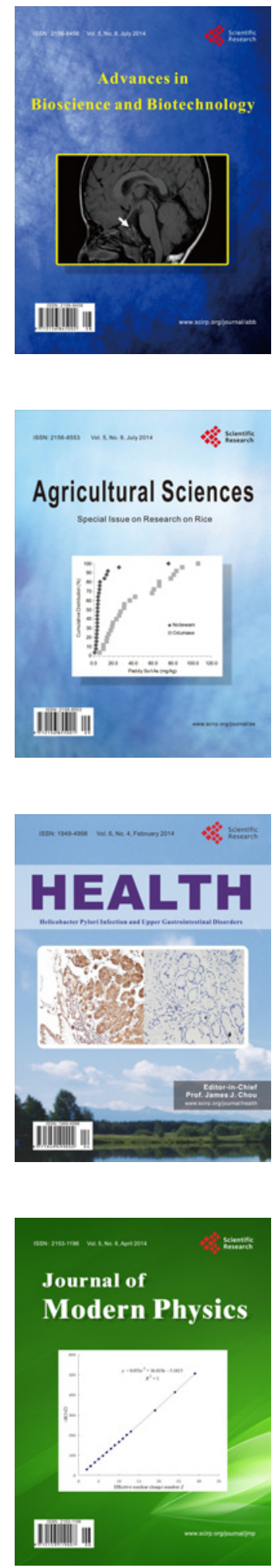
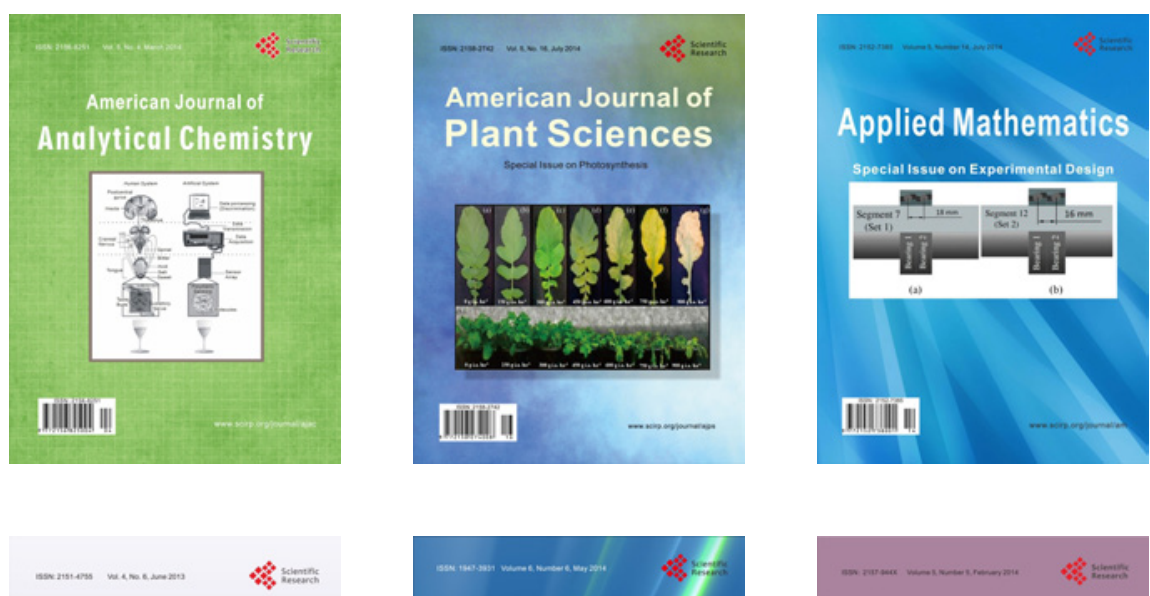

Creative Education
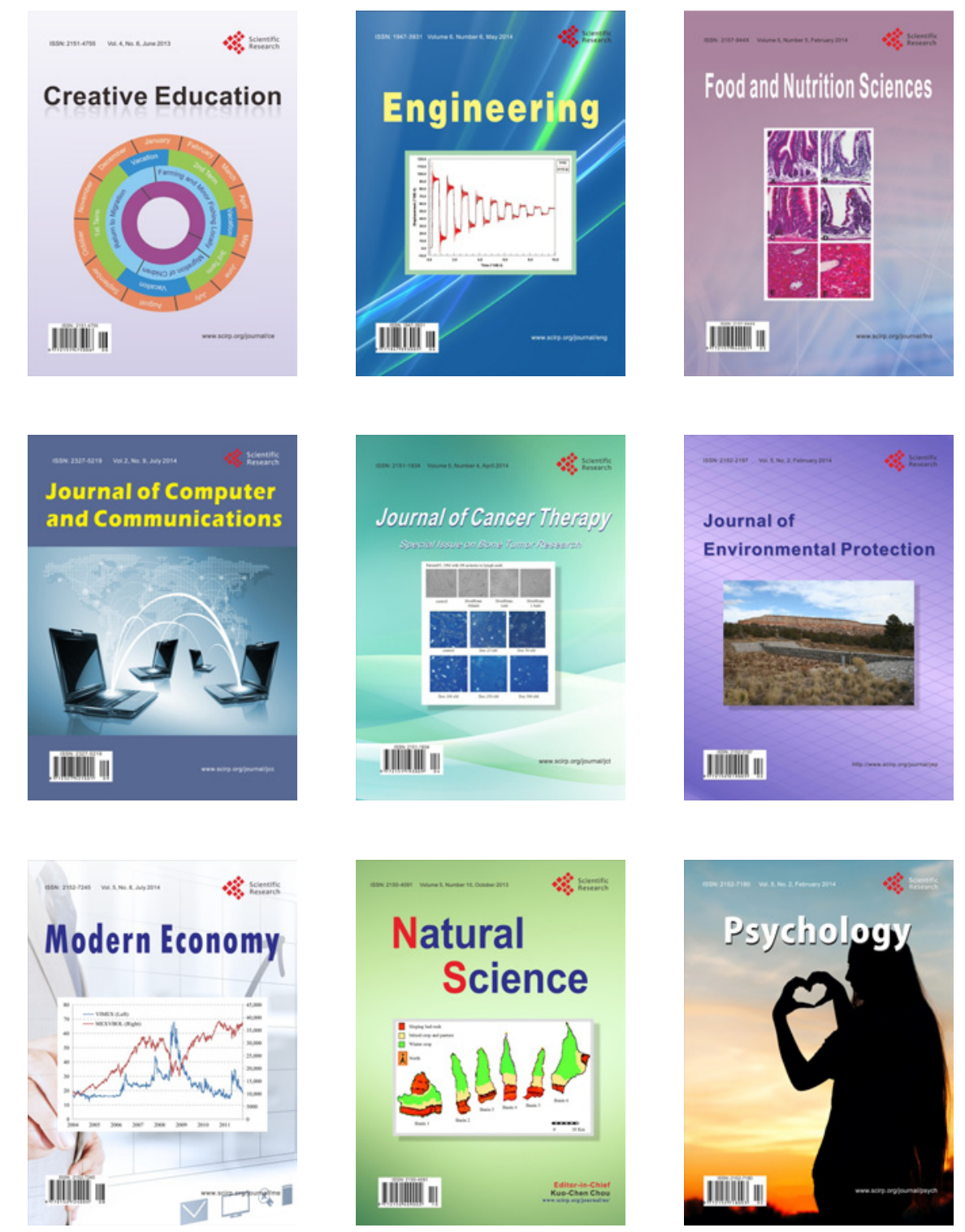